\title{
ASPEK DINAMIKA POPULASI KEPITING BAKAU Scylla serrata (Forsskal, 1775) DI PERAIRAN DISTRIK MERAUKE KABUPATEN MERAUKE PROVINSI PAPUA
}

\author{
Siti Masiyah \\ Staf Pengajar Faperik UNIMER-Merauke, e-mail: S.masiyah@yahoo.com
}

\begin{abstract}
ABSTRAK
Potensi sumberdaya alam di Kabupaten Merauke sangat luas, baik potensi sumberdaya yang dalam proses pemanfaatan maupun potensi untuk pengembangan sumberdaya alam. Penangkapan yang dilakukan terus menerus untuk memenuhi permintaan konsumen tanpa adanya suatu usaha pengaturan, dalam kurun waktu yang akan datang akan mengalami kelebihan tangkap (overfishing). Beverton dan Holt (1957) menyatakan bahwa salah satu data penting yang perlu diketahui sebagai bahan masukan untuk memperoleh pola pengaturan dan pengelolaan perikanan di perairan tersebut adalah aspek dinamika polulasi. Adapun parameter dinamika populasi tersebut meliputi : Kelompok umur, pertumbuhan, mortalitas, yield per rekruitmen yang ada di Kabupaten Merauke Provinsi Papua. Penelitian ini di laksanakan pada bulan Maret - Mei 2012 tepatnya di Distrik Merauke, Kabupaten Merauke. Untuk menduga pertumbuhan digunakan formula yang dikemukakan oleh Von Bertalanffy (Sparre et.al, 1999), Laju mortalitas alami (M) diduga dengan menggunakan rumus empiris rumus empiris Pauly (1983), Pendugaan laju kematian total (Z), laju eksploitasi (E), laju mortalitas penangkapan(F) dan $\mathrm{Y} / \mathrm{L}$ dianalisis dengan menggunakan metode Baverton dan Holt (Sparre. et al, 1999). Hasil penelitian didapatkan bahwa didapatkan kepiting : 1052 ekor Hasil pemetaan antara frekuensi dan tengah kelas didapatkan 23 kelas dengan interval 6 sebanyak tiga kelompok umur, Nilai panjang asimptot $\left(L_{\infty}\right)$ sebesar $177.8304 m m$, sedangkan koefisien laju pertumbuhan $(K)$ adalah 0.697 pertahun ( $\left.t_{0}\right)$ adalah sebesar -0.1417 pertahun) nilai mortalitas alami (M) yaitu 0.7598, mortalitas penangkapan $(F)=1.6054$ umur relatif, mortalitas total $(Z) 2.365$ umur relative nilai laju eksploitasi 0.6787 pertahun,Pemetaan Y/R 0.0467.
\end{abstract}

Kata Kunci: Kepulauan Banda, komunitas, lamun

\section{PENDAHULUAN}

1.1. Latar Belakang

Potensi sumberdaya alam di Kabupaten Merauke sangat luas, baik potensi sumberdaya yang dalam proses pemanfaatan maupun potensi untuk pengembangan sumberdaya alam. Salah satu potensi sumberdaya alam yang sudah termanfaatkan adalah kepiting bakau. Pemanfaatan yang semakin meningkat berdampak positif dalam meningkatkan kesejahteraan dan meningkatkan kesempatan kerja, namun juga dapat memiliki dampak negatif bila pemanfaatan tidak terkendali, Kasry (1996), menyatakan bahwa di beberapa tempat di Pulau Jawa, nelayan mulai sulit memperoleh hasil tangkapan kepiting bakau. Peningkatan permintaan pasar terhadap komoditas kepiting bakau dengan harga yang cukup tinggi, menyebabkan terjadinya penangkapan berlebihan (over exlpoitasi), yang merupakan salah satu penyebab penurunan populasi kepiting bakau dialam.

Walford (1957) menyatakan bahwa konservasi perikanan adalah kebijaksanaan yang dipakai terhadap sumber-sumber perikanan yang ada. Konservasi ini dapat berupa peraturan dan pembinaan dalam biologi, ekologi, ekonomi dan sosial. 
Pengelolaan perikanan dimaksudkan untuk menentukan atau menetapkan suatu keadaan seimbang dengan produksi maksimal per unit upaya penangkapan. Penangkapan yang dilakukan terus menerus untuk memenuhi permintaan konsumen tanpa adanya suatu usaha pengaturan, maka sumberdaya ini dalam kurun waktu yang akan datang akan mengalami kelebihan tangkap (overfishing) dan berakibat mengganggu kelestarian sumberdaya hayati perikanan. Beverton dan Holt (1957) menyatakan bahwa salah satu data penting yang perlu diketahui sebagai bahan masukan untuk memperoleh pola pengaturan dan pengelolaan perikanan di perairan tersebut adalah aspek dinamika polulasi.

Status dinamika populasi yang berkaitan dengan pengelolaan dan pemanfaatan sumberdaya perikanan kepiting bakau di Kabupaten Merauke selama ini belum pernah dilakukan penelitian. Penelitian ini merupakan salah satu upaya pengelolaan dan pemanfaat sumberdaya kepiting bakau dengan melihat beberapa parameter dinamika populasi. Adapun parameter dinamika populasi tersebut meliputi : Kelompok umur, pertumbuhan, mortalitas, yield per rekruitmen yang ada di Kabupaten Merauke Provinsi Papua. Hasil penelitian ini diharapkan dapat digunakan sebagai informasi dan bahan kajian untuk pengembangan dan pengelolaan potensi kepiting bakau di Indonesia, khususnya di Kabupaten Merauke.

\subsection{Tujuan Penelitian}

Penelitian ini bertujuan untuk menganalisis beberapa parameter dinamika populasi kepiting bakau Scylla serrata.

\section{BAHAN DAN METODE}

\subsection{Lokasi dan Rancangan Penelitian}

Penelitian ini di laksanakan pada bulan Maret - Mei 2012 tepatnya di Distrik Merauke, Kabupaten Merauke. Jenis penelitian ini yang digunakan adalah metode Populasi dan Sampel

Penelitian ini menggunakan total sampling yang berasal dari hasil penangkapan nelayan. Penarikan sampel dilakukan dalam interval waktu dua minggu sekali selama tiga bulan. Sampel kepiting bakau diukur lebar karapaks menggunakan kaliper.

\subsection{Analisis Data}

1. Pendugaan pertumbuhan

Untuk menduga pertumbuhan digunakan formula yang dikemukakan oleh Von Bertalanffy (Sparre et.al, 1999) dengan persamaan sebagai berikut :

$$
\mathbf{L}_{\mathrm{t}}=\mathrm{L} \infty\left(1-\exp ^{-K\left(t-t_{0}\right)}\right)
$$

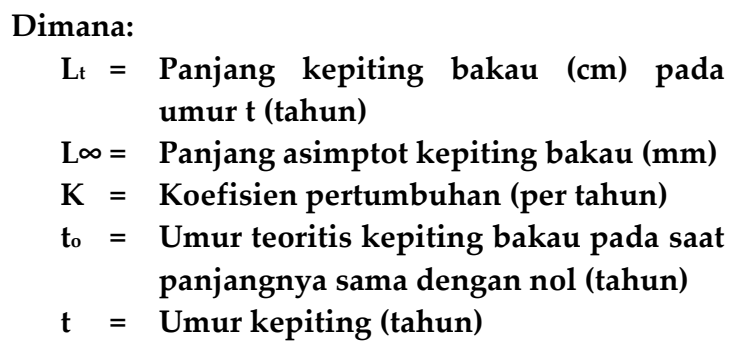

Sedangkan untuk menentukan panjang asimtot kepiting bakau $(\mathrm{L} \infty)$ dan koefisien laju pertumbuhan (K) digunakan metode Ford dan Walford dalam Sparre et al.(1999) yaitu dengan memplotkan $\mathrm{L}(\mathrm{t}+\Delta \mathrm{t})$ dan $\mathrm{L}(\mathrm{t})$ dengan persamaan berikut :

$$
L(t+\Delta t)=a+b . L(t)
$$

Setelah mendapatkan persaman regresi dari kedua hubungan kemudian dimasukkan ke dalam persamaan linier yaitu :

$$
\mathbf{Y}=\mathbf{a}+\mathbf{b} \mathbf{X}
$$

\section{Dimana:}

$a=L \infty(1-b), \quad b=\exp (-K . \Delta t)$

sehingga diperoleh :

$$
\mathrm{L} \infty=\frac{a}{1-b}, \mathbf{K}=\frac{-1}{\Delta t} \operatorname{Ln} \mathbf{b}
$$

Selanjutnya pendugaan umur teoritis pada saat panjang kepiting bakau sama dengan nol ( $\left.t_{0}\right)$ digunakan rumus empiris Pauly dalam Sparre et al. (1999) sebagai berikut:

$$
\begin{aligned}
\log \left(-t_{0}\right)= & -0,3922-0,2752 \log L_{\infty}-1,308 \\
& \log K
\end{aligned}
$$

Dimana :

$\mathrm{L}_{\infty}=$ Panjang asimptot kepiting bakau (mm)

$\mathrm{K}=$ Koefisien pertumbuhan (per tahun)

$t_{o}=$ Umur teoritis kepiting bakau pada saat panjangnya sama dengan nol (tahun) 
2. Pendugaan mortalitas alami (M)

Laju mortalitas alami (M) diduga dengan menggunakan rumus empiris rumus empiris Pauly (1983) adalah sebagai berikut :

$\ln \mathrm{M}=-0,152-0,279$ In $\mathrm{L} \infty+0,6543$ In $\mathrm{K}+0,4634$ In $\mathrm{T}$

Dimana:

$$
\begin{aligned}
& \mathbf{M}=\text { Mortalitas alami (Per Tahun) } \\
& \mathbf{L} \infty=\text { Panjang asimptot kepiting bakau }(\mathrm{mm}) \\
& \mathbf{K}=\text { Koefisien pertumbuhan (per tahun) } \\
& T=\text { Suhu permukaan rata-rata tahunan }\left({ }^{\circ} \mathrm{C}\right)
\end{aligned}
$$

3. Pendugaan mortalitas total ( $\mathrm{Z}$ )

Pendugaan laju kematian total (Z) dianalisis dengan menggunakan metode Baverton dan Holt (Sparre. et al, 1999), dimana formula yang dipergunakan adalah :

$$
Z=K\left[\frac{L \infty-\bar{L}}{\bar{L}-L^{\prime}}\right]
$$

Dimana :

$$
\begin{aligned}
\mathrm{Z}= & \text { Laju kematian total ( per tahun) } \\
\mathrm{L} \infty^{\prime}= & \begin{array}{l}
\text { Panjang asimptot kepiting bakau } \\
(\mathrm{mm})
\end{array} \\
\mathrm{K}= & \begin{array}{l}
\text { Koefisien laju pertumbuhan (per } \\
\text { Tahun) }
\end{array} \\
\bar{L}= & \text { Panjang rata-rata kepiting bakau yang } \\
& \text { tertangkap (mm) } \\
L^{\prime}= & \text { Batas terkecil dari panjang tubuh } \\
& \begin{array}{l}
\text { kepiting bakau yang tertangkap } \\
\text { secara penuh }(\mathrm{mm}) .
\end{array}
\end{aligned}
$$

4. Pendugaan mortalitas Penangkapan (F)

Mortalitas penangkapan diperoleh dengan persamaan $Z=F+M$, sehingga $F=Z$ $M$ dan laju eksploitasi (E) diperoleh dengan menggunakan rumus Beverton dan Holt yaitu $\mathrm{E}$ $=F / Z$, dimana $F$ adalah nilai mortalitas penangkapan dan $\mathrm{Z}$ adalah mortalitas total (Sparre et al., 1999).

\section{Yield Per Recruitment}

Diperoleh dengan menggunakan persamaan Baverton dan Holt (Sparre. et al., 1999).

$$
\begin{gathered}
Y / R=E \cdot U^{M / K}\left(1-\frac{3 U}{1+m}+\frac{3 U^{2}}{1+2 m}-\frac{U^{3}}{1+3 m}\right) \\
U=1-\frac{L^{\prime}}{L \infty}
\end{gathered}
$$

$$
m=\frac{1-E}{M / K}
$$

Dimana :

$$
\mathbf{M}=\text { Mortalitas alami (per Tahun) }
$$

$L^{\prime}=$ Batas terkecil dari panjang tubuh kepiting bakau yang tertangkap (mm)

$\mathrm{L}^{\infty}=$ Panjang asimptot kepiting bakau (mm)

$\mathrm{K}=$ Koefisien laju pertumbuhan (per Tahun).

\section{HASIL DAN PEMBAHASAN}

\subsection{Kelompok Umur}

Selama penelitian di Distrik Merauke didapatkan kepiting : 1052 ekor. Hasil pemetaan antara frekuensi dan tengah kelas didapatkan 23 kelas dengan interval 6 sebanyak tiga kelompok umur, kelompok umur pertama dengan kisaran lebar karapas 40-94mm sebanyak 158 ekor, kelompok umur kedua berada pada kisaran lebar karapas 88-142mm sebanyak 677ekor dan kelompok umur ke tiga berada pada kisaran lebar 136-178 $\mathrm{mm}$ sebanyak 248 ekor.Hubungan antara frekuensi ( F )hasil tangkapan dan tengah kelas dapat dilihat pada Gambar 1.

Dari Gambar 1 di atas terlihat bahwa hasil penangkapan kepiting bakau di Distrik Merauke berukuran kecil, ukuran sedang dan ukuran besar. Ukuran lebar karapas terbanyak terdapat pada interval kelas $121-127 \mathrm{~mm}$ dengan frekuensi sebanyak 124 ekor, sedangkan frekuensi lebar karapas terendah pada interval kelas 97-103mm dengan frekuensi 4 ekor.

Dari gambar 1 tampak terbentuk tiga puncak tengah kelas panjang dengan frekuensi observasi yang cukup jauh berbeda. Hal ini menunjukkan bahwa populasi kapiting bakau (Scylla serrata) di perairan Distrik Merauke terdiri atas tiga kelompok umur. Dimana secara berurut puncak tertinggi ke terendah yaitu pada masing-masing lebar tengah kelas yaitu $121 \mathrm{~mm}$ dengan frekuensi sebanyak 172 ekor, panjang tengah kelas $145 \mathrm{~mm}$ dengan frekuensi 78 ekor, dan lebar tengah kelas $67 \mathrm{~cm}$ dengan frekuensi sebanyak 34 ekor. Dimana Fobs. didistribusi normalkan dengan menggunakan nilai Fc (frekuensi terhitung) atau frekuensi teoritis. 


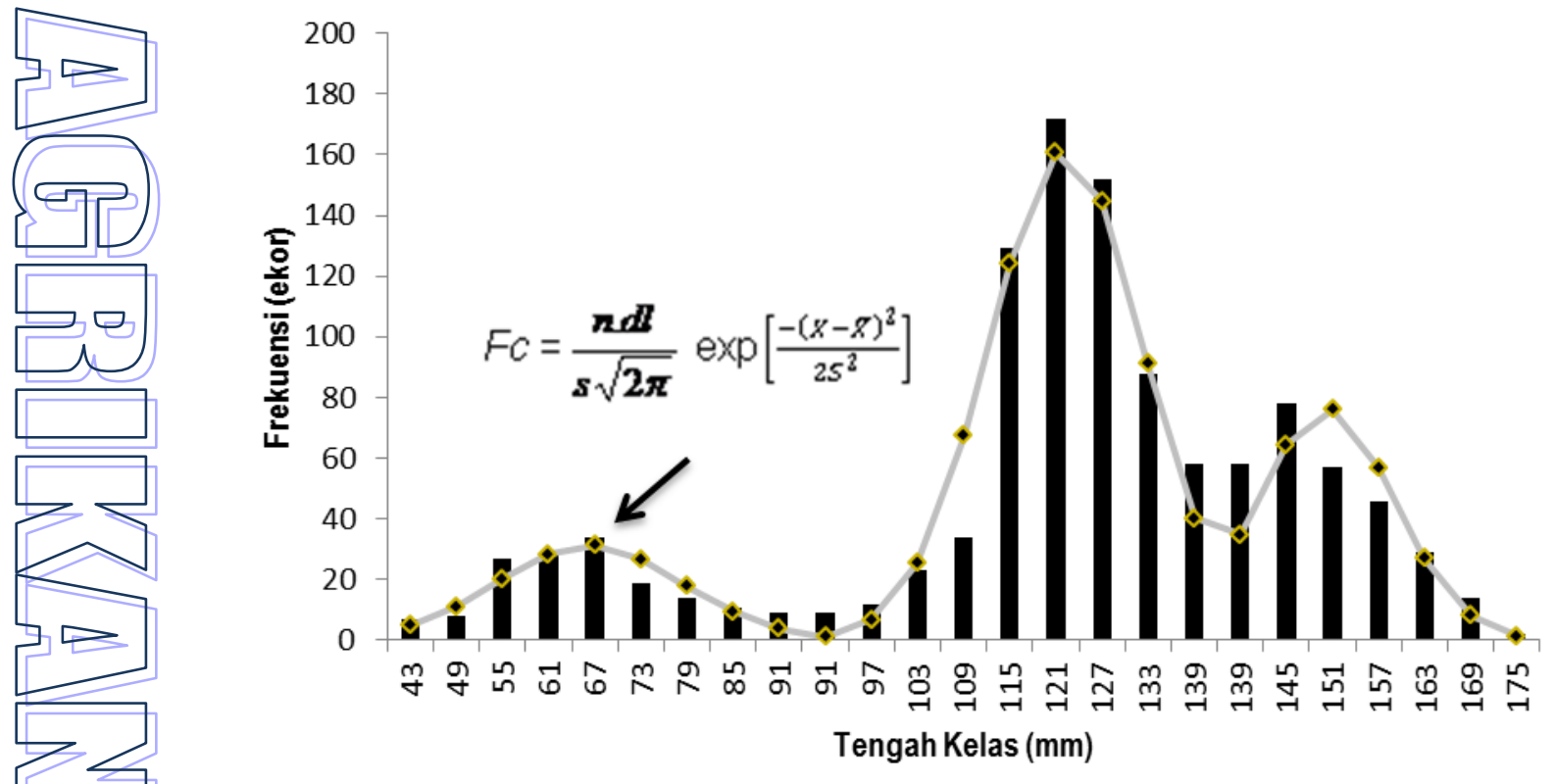

Gambar 1. Hubungan antara frekuensi (F) hasil tangkapan dan tengah kelas (mm) kepiting bakauScylla serrata (Forsskal, 1775) di Distrik Merauke, Kabupaten Merauke

\subsection{Pertumbuhan}

Berdasarkan hasil analisis dengan menggunakan metode Ford-Walford (Sparre,et al.,1999) diperoleh nilai panjang asimptot $(\mathrm{L} \infty)$ sebesar $177.8304 \mathrm{~mm}$, sedangkan koefisien laju pertumbuhan (K) adalah 0.697 pertahun. Laju pertumbuhan (K) kepiting bakau di perairan Distrik Merauke menunjukkan nilai yang tinggi karena berada diatas 0,5 pertahun, sehingga waktu yang dibutuhkan untuk mencapai asimptotnya cepat. Hal ini sesuai dengan pernyataan (Sparre, et al.,1999) bahwa ikan yang memiliki laju koefisien yang tinggi akan membutuhkan waktu yang cepat untuk mencapai panjang asimptotnya dan sebaliknya. Panjang asimptot dan koefisien laju pertumbuhan perbeda dengan hasil penelitian (Wijaya,et al., 2010) di perairan Muara Sanggata Taman Nasional Kutai didapatkan lebar asimptot jantan : $151.2 \mathrm{~mm}$, betina : $161.18 \mathrm{~mm}$ dan koefisien laju pertumbuhan jantan: 1.2 dan betina 1.5 pertahun. Hasil penelitian Ward et $a l ., 2008$ di Northern Territory, Australia lebar asimptot jantan $152.5 \mathrm{~mm}$, betina $185.4 \mathrm{~mm}$ dan koefisien laju pertumbuhan jantan : 1.46 dan betina :0.81 pertahun. Penelitian yang dilakukan Zafar et al., 2006 di perairan India panjang asimptot jantan: $105.9 \mathrm{~mm}$, betina : $10.5 \mathrm{~mm}$ dengan koefisien laju pertumbuhan jantan:0.28 dan betina: 0.36 pertahun. Perbedaan hasil penelitian di Taman Nasional Kutai,Northern Territory Australia, India dengan di perairan Distrik Merauke, Kabupaten Merauke berbeda diduga disebabkan oleh kondisi lingkungan pada Distrik Merauke berbeda, kondisi mangrove sebagian sudah banyak mengalami pengrusakan,, ekosistem yang sangat dekat dengan pemukiman penduduk, banyaknya masyarakat suku (penduduk) asli bekerja mencari kepiting menyebabkan semakin banyak pula alat tangkap yang beroperasi, sehingga ukuran panjang asimptot dan koefisien laju pertumbuhan kepiting bakau berbeda. Selain itu, menurut pendapat Nontji (2007) bahwa setiap perairan mempunyai sifatsifat yang berbeda dalam struktur geografi, sifat musim hujan dan kemarau, serta pola siklus air. Oleh sebab itu pertumbuhan organisme yang hidup didalamnya akan mempunyai bentuk dan ukuran yang berbeda.

Dengan menggunakan penurunan rumus dari persamaan Von Bertalanffy (Sparre, et al., 1999) maka didapatkan umur teoritis Kepiting bakau Scylla serrata di Distrik Merauke (Stasiun I) pada saat permulaan $\left(t_{0}\right)$ adalah sebesar -0.1417 pertahun. Berdasarkan nilai parameter pertumbuhan yang diperoleh $(L \infty, K, t 0)$ 
kepiting bakau di perairan Distrik Merauke maka diperoleh persamaan Von Bertalanffy sebagai berikut:

$$
\mathrm{Lt}=177.8304\left(1-\mathrm{e}^{-0.697(t+0.1417)}\right)
$$

Dari persamaan tersebut maka dapat diketahui lebar kepiting bakau Scylla serrata dari berbagai umur relatif, sehingga di peroleh pertambahan lebar kepiting bakau untuk setiap tahunnya hingga mencapai panjang asimptotnya.Dengan menghubungkan umur relatif sebagai sumbu $x$ terhadap lebar kepiting bakau setiap tahunnya sebagai sumbu $Y$, maka dapat dibentuk kurva pertumbuhannya (Gambar 2).

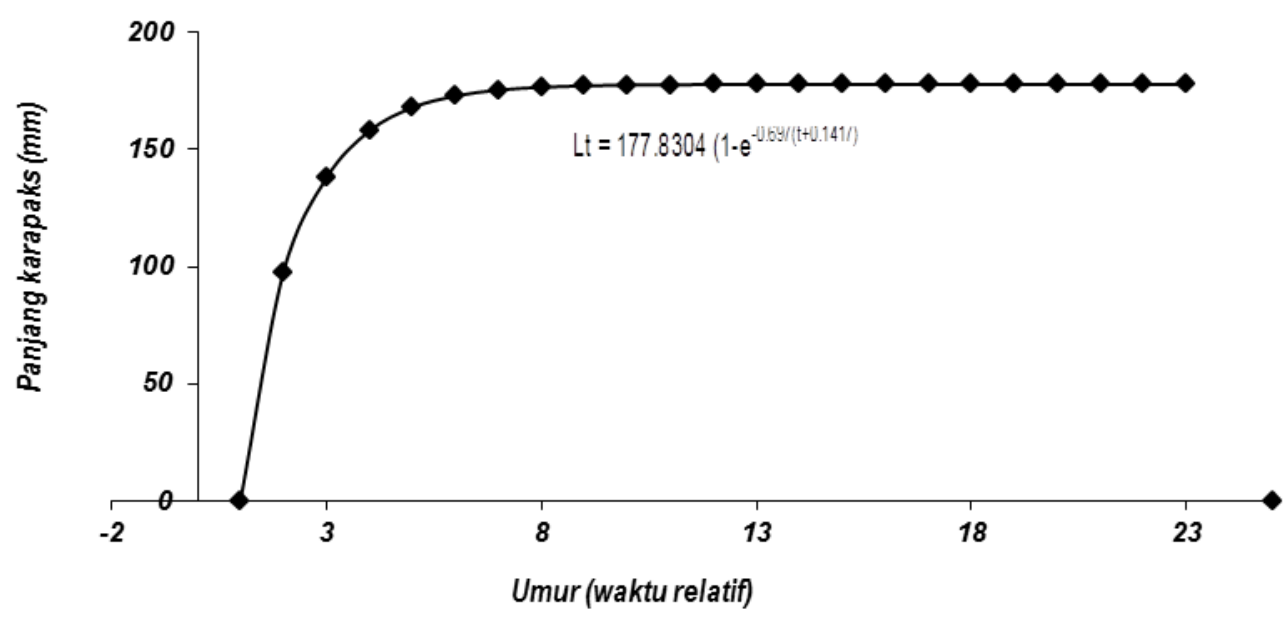

Gambar 2. Kurva pertumbuhan kepiting bakau Scylla serrata (Forsskal, 1775) di Distrik Merauke, Kabupaten Merauke

Dari persamaan tersebut dapat diduga lebar kepiting bakau Scylla serrata (Forsskal, 1775) di Distrik Kimaam, Kabupaten Merauke untuk setiap tahunnya hingga mencapai panjang asimptotnya dengan asumsi kepiting ini melakukan pemijahan sekali dalam setahun. Pendugaan pertumbuhan kepiting bakau Scylla serrata (Forsskal, 1775) Distrik MeraukeKabupaten Merauke. Bentuk kurva seperti gambar di atas disebut kurva pertumbuhan spesifik dimana ikan pada fase awal dari hidupnya mengalami pertumbuhan yang cepat dan diikuti pertumbuhan yang lambat pada umur tua. Berdasarkan kurva pertumbuhan spesifik diatas menunjukkan bahwa pertambahan lebar kepiting bakau Scylla serrata(Forsskal, 1775) di Distrik Merauke, Kabupaten Merauke yang cepat terjadi pada waktu umur muda dan semakin lambat seiring dengan bertambahnya umur sampai mencapai panjang asimptotnya dimana kepiting tidak bertambah lebar lagi.Selain itu juga pertumbuhan cepat bagi ikan yang berumur muda terjadi karena energi yang didapatkan dari makanan sebagian besar digunakan untuk pertumbuhan.Pada ikan tua energi yang didapatkan dari makanan tidak lagi digunakan untuk pertumbuhannya, tetapi hanya digunakan untuk mempertahankan dirinya dan mengganti sel-sel yang rusak. Hal serupa juga diungkapkan oleh Nikolsky (1969) bahwa ikan-kan muda akan memiliki pertumbuhan yang relatif cepat, sedang ikanikan dewasa akan semakin lambat untuk mencapai panjang asimptotnya atau panjang maksimumnya, selanjutnya akan terhenti pada saat mencapai panjang asimptotnya. Selanjutnya Azis (1989) mengemukakan bahwa panjang badan terhadap waktu memperlihatkan suatu level yang seragam dengan laju pertumbuhan pada permulaan, selanjutnya menurun menuju panjang maksimum teoritis atau panjang asimptotnya.

\subsection{Mortalitas dan laju eksploitasi}

Pendugaan laju mortalitas merupakan hal yang penting dalam menganalisis dinamika populasi kepiting bakau, laju mortalitas dapat memberikan gambaran mengenai besarnya stok yang dapat dieksploitasi terhadap suatu populasi.Pendugaan analisis laju mortalitas total (Z) dianalisa dengan menggunakan 
metode Beverton dan Holt (Sparre, et al.,1999). Berdasarkan nilai parameter pertumbuhan yang diperoleh maka dari hasil perhitungan didapatkan nilai laju mortalitas total (Z), laju mortalitas alami (M) dan laju mortalitas penangkapan (F) masing-masing sampel kepiting bakau dapat dilihat pada Tabel 1.

Tabel 1. Nilai Dugaan Mortalitas kepiting bakau (Scylla serrate Forsskal, 1775) di Distrik Merauke Kabupaten Merauke.

\begin{tabular}{lc}
\hline \multicolumn{1}{c}{ Parameter populasi } & Nilai dugaan (umur relatif) \\
\hline Mortalitas total (Z) & 2.3653 \\
Mortalitas alami (M) & 0.7598 \\
Mortalitas penangkapan (F) & 1.6054 \\
Laju eksploitasi (E) & 0.6787 \\
\hline
\end{tabular}

Tabel 1 menunjukkan bahwa laju mortalitas penangkapan (F) kepiting bakau lebih besar dari pada laju mortalitas alami (M). Hal ini menunjukkan bahwa kematian kepiting bakau di perairan Distrik Merauke Kabupaten Merauke umumnya disebabkan karena penangkapan.

Pada Tabel 1 dapat dilihat nilai mortalitas alami (M) dari hasil penangkapan kepiting bakau di Distrik Merauke yaitu 0.7598, mortalitas penangkapan $(F)=1.6054$ umur relatif, mortalitas total $(\mathrm{Z}) 2.365$ umur relative dengan mengetahui nilai mortalitas total (Z) dan mortalitas penangkapan (F) maka di peroleh nilai laju eksploitasi 0.6787 .

Hasil penelitian La Sara (2010) di Lawele Bay Sulawesi Selatan didapatkan laju mortalitas total (Z) kepiting jantan 3.68 umur relatifdan betina: 2.53 umur relatif. Laju mortalitas (M) alami kepiting jantan : 2.48umur relatif, betina: 1.78 pertahun.Ward et al., (2006) yang dilakukan di perairan Australia, didapatkan nilai mortalitas total (Z) kepiting jantan:0.84dan betina: 0.96 , laju mortalitas alami kepiting jantan: 0.49, jantan: 0.58pertahun, laju mortalitas penangkapan jantan: 0.35 dan betina: 0.38. Siahainenia (2008) yang dilakukan di Mayangan Subang Jawa Barat, laju mortalitas total kepiting Scylla serrata jantan: 3.02 dan betina 2.55 sedangkan laju mortalitas alami jantan: 3.03 dan betina 2.55. Iskandar dan Bahrudin (1991) pada periran Intan Selatan Riau, didapatkan nilai $M=2.24 /$ tahun dan nilai $\mathrm{F}=0.8 /$ tahun. Bila dikaji menurut wilayah atau perairan menunjukkan bahwa laju mortalitas alami dari kepiting bakau pada wilayah perairan Distrik Merauke dengan perairan Lawela Bay Sulawesi selatan, India, Subang
Jawa barat dan Riau berbeda.Hal ini mungkin disebabkan karena kondisi parameter lingkungan yang berfluktuasi, serta kelimpahan makanan alami kepiting bakau. Menurut Paundanan ( 1990), menyatakan bahwa mortalitas alami kepiting bakau, disebabkan oleh keadaaan lingkungan yang kompleks, yang dipengaruhi langsung oleh kuantitas dan kualitas pasokan air laut, sehingga menyebabkan fluktuasi parameter lingkungan secara tepat dan drastis. Selain itu karena kondisi lingkungan, minimnya sumber makanan alami kepiting bakau dapat memicu persaingan antar induvidu terhadap sumber makanan alaminya. Persaingan dilakukan melalui pertarungan sehingga dapat mengakibatkan kematian atau bahkan kanibalisme, yang merupakan sifat dasar kepiting bakau.

Nilai laju eksploitasi $(0,6787)$ kepiting bakau (Scylla serrata) di perairan Kabupaten Merauke Distrik Merauke telah melebihi laju eksploitasi optimalnya $(0,55)$. Apabila nilai E yang diperoleh lebih besar dari 0,55 dapat dikategorikan lebih tangkap biologis yaitu lebih tangkap pertumbuhan terjadi bersamasama dengan lebih tangkap recruitment.Lebih tangkap pertumbuhan yaitu tertangkapnya ikan-ikan muda yang berpotensi sebagai stok sumber daya perikanan sebelum mereka mencapai ukuran yang pantas untuk ditangkap sedangkan lebih tangkap rekruitmen yaitu jika jumlah ikan-ikan dewasa dalam stok terlalu banyak dieksploitasi, sehingga reproduksi ikan-ikan muda juga berkurang (Pauly, 1983). 


\subsection{Yield per recruitmen}

Pendugaan stok yeild per rekruitment (Y/R) merupakan salah satu model yang dapat digunakan sebagai dasar strategi pengelolaan perikanan disamping model-model stok recruitment dan surplus produksi. Hasil perhitungan Y/R lihat pada Gambar 3.

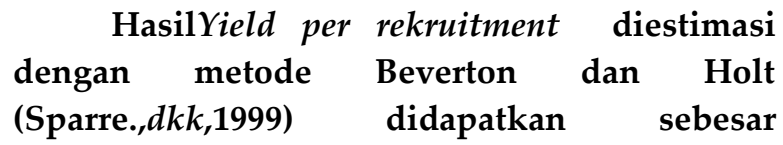
0.0467gram per rekruitmen yang berarti bahwa setiap rekruitment yang terjadi terdapat 0.0467gram yang dapat diambil sebagai hasil tangkapan.

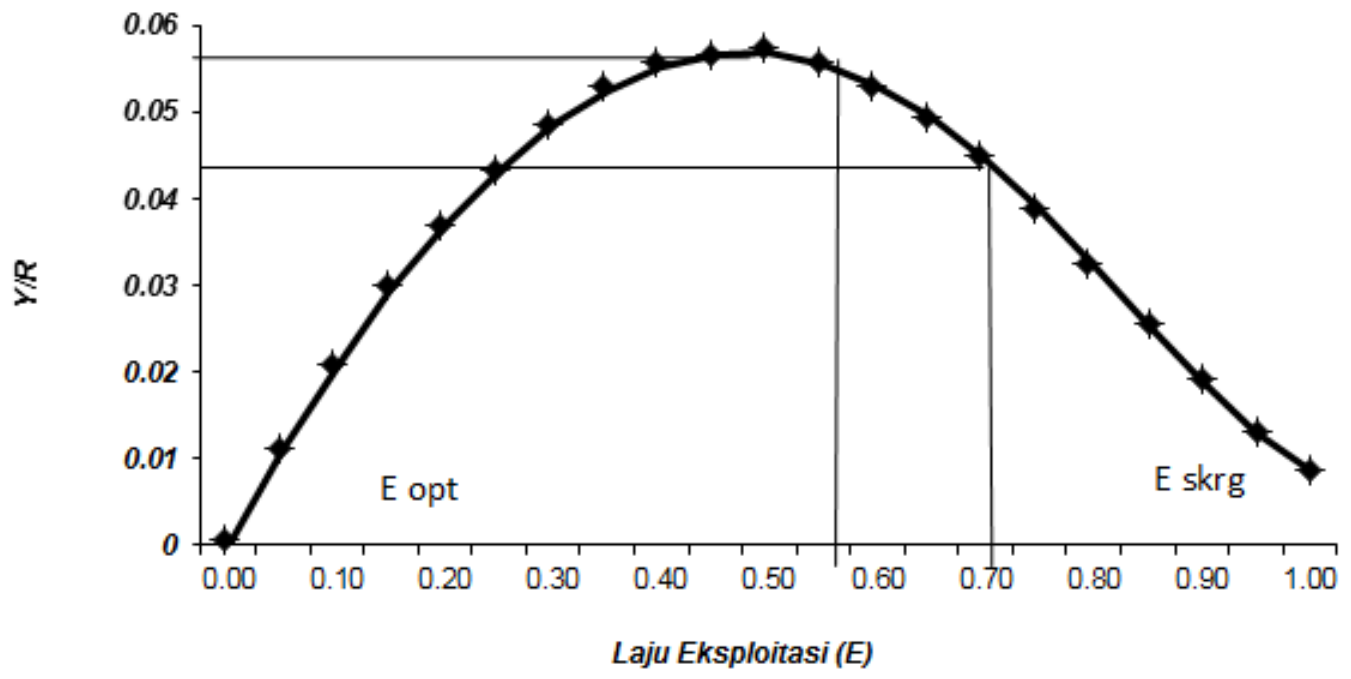

Gambar 3. Kurva Y/R Beverton dan Holt kepiting bakau Scylla serrata (Forsskal, 1775)di DistrikMeraukeKabupaten Merauke.

Pemetaan antara Y/R dan laju eksploitasi didapatkan bahwa laju eksploitasi pada $Y / R$ 0.0467 di dapatkan E 0.6787 pertahun sedangkan Eopt adalah 0.5000 dengan $Y / R$ sebesar 0.0594 . Berdasarkan nilai $E$ dan nilai $Y / R$ (porsi/bagian yang boleh dilakukan penangkapan dari rekruitmen) yang diperoleh selama penelitian, dapat disimpulkan bahwa nilai E pada Distrik Merauke melebihi nilai E optimum sehingga didapatkan nilai $Y / R$ semakin kecil dari nilai optimumnya kondisi ini dapat dikatakan mendekati over eksploitasi karena telah melampaui nilai optimalnya dan hasil tangkapan yang diperoleh semakin berkurang. Perhitungan Pendugaan Y/R kepiting bakau (Scylla serrate Forsska, 1775) di Distrik Merauke Kabupaten Merauke

Untuk memperoleh hasil maksimun dan lestari, maka usaha penangkapan atau laju eksploitasi kepiting bakau di Distrik Merauke perlu dikurangi alat tangkap yang beroperasi. Menurut Gulland, (1983) bahwa hasil tangkapan akan mencapai tingkat optimal apabila $E=F / Z$ atau $E$ optimalnya sama dengan 0,5 .

\section{PENUTUP}

Berdasarkan hasil penelitian Aspek Dinamika populasi dan potensi kepiting bakau Scylla serrata (Forsskal 1775) pada ekosistem mangrove di Kabupaten Merauke, dapat disimpulkan berikut ini:

1. Hasil penelitian pada Distrik Merauke pemetaan antara frekuensi dan tengah kelas didapatkan 23 kelas dengan interval 6 sebanyak tiga kelompok umur,

2. Nilai panjang asimptot $(\mathrm{L} \infty)$ sebesar $177.8304 \mathrm{~mm}$, sedangkan koefisien laju pertumbuhan (K) adalah 0.697 pertahun ( $t_{0}$ ) adalah sebesar $\mathbf{- 0 . 1 4 1 7}$ pertahun).

3. nilai mortalitas alami (M) yaitu 0.7598, mortalitas penangkapan $(F)=1.6054$ umur relatif, mortalitas total $(\mathrm{Z}) 2.365$ umur relative nilai laju eksploitasi 0.6787 pertahun, Pemetaan Y/R 0.0467. 


\section{DAFTAR PUSTAKA}

Aziz, K.A. 1989. Bahan Pengajaran Dinamika Populasi Ikan Departemen Pendidikan dan Kebudayaan. Dirjen DIkti. Pusat Antar Universitas Ilmu Hayat. Institut Pertanian Bogor. Bogor

Beverton,R.J.H. and S.J Holt,. 1957. On The Dynamics of exploited fish population. Fish Inverst.,London 2 (19): 533p.

Bhattacharya, C. G. 1967. A Simple Method of Resolution, A Distribution In To Gaussion Componen. Biometris 23

Gulland, J.A. 1983. Fish Stock Assesment A Manual of Basic Methocls. Willey. New York.

Nikolsky, G.V 1969. Theory of fish Population Dynamic, as the Biological Background of Rational Exploitation and the Manajement of Fishery resources, translated by Bradley.Oliver and Boy, 323 pp.

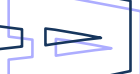

Nontji A. 2007. Laut nusantara. Penerbit Djambatan. Jakarta

Pauly, D. 1983. A. Selection of Sample Method for Assessment Tropical Fish Stock. Fao Fish Tech. New York.

Paundanan B. 1990. Potensi dan beberapa parameter dinamika populasi kepiting bakau (Scylla serrata forsskal, 1775) di perairan Tamuku Luwu. (Thesis). Jurusan FAPET UNHAS

Sparre,P.danS.C.Venema.1999.IntroduksiPengkajianStokIkanTropis. Buku I.Manual. Pusat Penelitiandan Pengembangan Perikanan.Jakarta.438p

Sara La. 2010. Studi on the size structure and population parameter of mud crab Scylla serrata in Lawela Bay, Southeast Sulawesi, Indonesia. Journal of Coastal Development 13:133-147

Wijaya N I, F. Yulianda, M Boer, S Juwana.2010. Biologi Populasi kepiting Bakau (Scylla serrta F) Di Habitat Mangrove Taman Nasional Kutai Kabupaten Kutai Timur.Jurnal Issn 0125 9830. Pusat Penelitian Lipi.

Ward, T.M., Schmarr and R. McGarvey. 2008. Northern muc crab fishery: 2007 stock assessment. Sardi Aquatic Sci. Publ. No: F 2007/000926-1. Sardi Res. Rep. Ser. No.244 West Beach, South Australia.

Zafar, M., S.M.N. Amin and M.M. Rahman. 2006. Population dynamics of mud crab (Scylla serrate) in the southern coastal regional of Banglades. Asian Fish. Sci. 19:43-50 